Article

\title{
Emission Characteristics of a CI Engine Running with a Range of Biodiesel Feedstocks
}

\section{Belachew Tesfa *, Fengshou Gu, Rakesh Mishra and Andrew Ball}

Center for Efficiency and Performance Engineering, University of Huddersfield, Huddersfield HD1 3DH, UK; E-Mails: f.gu@hud.ac.uk (F.G.); r.mishra@hud.ac.uk (R.M.); a.ball@hud.ac.uk (A.B.)

* Author to whom correspondence should be addressed; E-Mail: b.c.tesfa@hud.ac.uk; Tel.: +44-148-447-3677; Fax: +44-148-447-1106.

Received: 4 November 2013; in revised form: 7 January 2014 / Accepted: 8 January 2014 / Published: 16 January 2014

\begin{abstract}
Currently, alternative fuels are being investigated in detail for application in compression ignition (CI) engines resulting in exciting potential opportunities to increase energy security and reduce gas emissions. Biodiesel is one of the alternative fuels which is renewable and environmentally friendly and can be used in diesel engines with little or no modifications. The objective of this study is to investigate the effects of biodiesel types and biodiesel fraction on the emission characteristics of a CI engine. The experimental work was carried out on a four-cylinder, four-stroke, direct injection (DI) and turbocharged diesel engine by using biodiesel made from waste oil, rapeseed oil, corn oil and comparing them to normal diesel. The fuels used in the analyses are B10, B20, B50, B100 and neat diesel. The engine was operated over a range of engine speeds. Based on the measured parameters, detailed analyses were carried out on major regulated emissions such as $\mathrm{NO}_{\mathrm{x}}, \mathrm{CO}, \mathrm{CO}_{2}$, and THC. It has been seen that the biodiesel types (sources) do not result in any significant differences in emissions. The results also clearly indicate that the engine running with biodiesel and blends have higher $\mathrm{NO}_{\mathrm{x}}$ emission by up to $20 \%$. However, the emissions of the CI engine running on neat biodiesel (B100) were reduced by up to $15 \%, 40 \%$ and $30 \%$ for $\mathrm{CO}, \mathrm{CO}_{2}$ and $\mathrm{THC}$ emissions respectively, as compared to diesel fuel at various operating conditions.
\end{abstract}

Keywords: compression engine; biodiesel blend; nitrogen oxides; carbon dioxide; carbon monoxide; total hydrocarbon 


\section{Introduction}

Current and future emission regulations are, and will become, more stringent and as a consequence, the transport sector is undergoing rapid transformation in order to comply with these regulations. In addition, fossil fuel demand is continuously increasing globally, the result of which is the rapid depletion of fossil fuel deposits [1]. Such problems are compelling countries to now focus on developing or finding alternative fuels [2]. The major alternative fuels being used in automotive transport are ethanol, hydrogen and biodiesel. Ethanol technology is successfully established and commercialised in both developing and developed countries. However, ethanol use is limited only to spark ignition engines. Furthermore, ethanol use is also limited to maximum blend strengths of up to $15 \%$ only because higher blend strengths result in fuel injection system problems [3]. Hydrogen-based fuel cells could become a viable alternative to fossil fuels, however, to make its use commercially viable, many technical challenges need to be addressed, for example, complexity in hydrogen production, requirements of special infrastructure for its storage, and high fuel cell production costs. In spite of research advances on hydrogen-powered fuel cells, diesel engines are expected to remain in use for high-power applications, such as rail road locomotives, ships and over land transport trucks [4]. A large number of studies have shown that biodiesel is one of the most promising renewable, alternative and environmentally friendly biofuels which could be used in diesel engines, with little or no requirement of engine modifications [5-9]. It has also been shown that biodiesel has significant potential to reduce $\mathrm{CO}_{2}, \mathrm{CO}$, THC and PM emissions [10,11]. Lapuerta et al. [12] and Xue et al. [13] carried out a thorough review of publications on the characteristics of emissions of engines using biodiesel and its blends and their conclusions are summarized in Table 1.

Table 1. Estimated share of literature (in \% number of publications) on effect of pure biodiesel on engine performance and emission in comparison with diesel [12,13].

\begin{tabular}{|c|c|c|c|c|c|c|}
\hline \multirow[t]{2}{*}{ Parameters } & \multicolumn{2}{|c|}{$\begin{array}{c}\text { Increasing trend number } \\
\text { of papers }(\%)\end{array}$} & \multicolumn{2}{|c|}{$\begin{array}{c}\text { Similar trend number } \\
\text { of papers }(\%)\end{array}$} & \multicolumn{2}{|c|}{$\begin{array}{c}\text { Decreasing trend number } \\
\text { of papers }(\%)\end{array}$} \\
\hline & Lapuerta et al. & Xue et al. & Lapuerta et al. & Xue et al. & Lapuerta et al. & Xue et al. \\
\hline $\mathrm{NO}_{\mathrm{x}}$ emission & 85 & 65.2 & 10 & 5.8 & 5 & 29.0 \\
\hline PM emission & 3 & 9.6 & 2 & 2.7 & 95 & 87.7 \\
\hline THC emission & 1 & $\mathrm{NR}^{*}$ & 3 & NR & 95 & NR \\
\hline $\mathrm{HC}$ emission & NR & 5.3 & NR & 5.3 & NR & 89.5 \\
\hline $\mathrm{CO}$ emissions & 2 & 10.6 & 7 & 3.0 & 90 & 84.4 \\
\hline $\mathrm{CO}_{2}$ & NR & 46.2 & NR & 15.4 & NR & 38.5 \\
\hline Aromatic compounds & NR & 0 & NR & 15.4 & NR & 84.6 \\
\hline Carbonyl compounds & NR & 80.0 & NR & 0 & NR & 20.0 \\
\hline
\end{tabular}

NR: not reported

Most of the literature reviewed showed that the use of biodiesel fuels caused increases in $\mathrm{NO}_{\mathrm{x}}$ emissions [14-17]. As presented in Table 1, Lapuerta et al. [12] and Xue et al. [13] carried out a thorough review of publications on the $\mathrm{NO}_{\mathrm{x}}$ emission of engines using biodiesel and its blends. Lapuerta et al. [12] and Xue et al. [13] reported that in excess of $85 \%$ and $65 \%$ of researchers agreed that the $\mathrm{NO}_{\mathrm{x}}$ emission of an engine fuelled with biodiesel was higher than that of engines running with 
diesel only. The first reason behind this observation is early initiation of engine combustion when running with biodiesel as a consequence of the advanced injection derived from the physical properties of biodiesel such as viscosity, density, compressibility and speed of sound [18]. When biodiesel is injected, the pressure rise produced by the pump is quicker as a consequence of its lower compressibility (higher bulk modules) and the pressure wave propagates more quickly towards the injectors as a consequence of its higher sound velocity $[19,20]$. This causes earlier ignition which results in higher temperature peaks and $\mathrm{NO}_{\mathrm{x}}$ formation rates. A small number of researchers have reported that the $\mathrm{NO}_{\mathrm{x}}$ emissions are reduced when biodiesel is used as a fuel $[10,11,21,22]$. Recently, Pala-En et al. [23] explained the main reason for $\mathrm{NO}_{\mathrm{x}}$ reduction is due to higher degrees of saturation and the longer chain lengths and higher cetane numbers.

The Lapuerta et al. [12] and Xue et al. [13] studies showed that $90 \%$ and $84 \%$ of the reviewed papers show decreases in $\mathrm{CO}$ emissions when the engines ran with biodiesel. The researchers explained that the main reason for reduction of $\mathrm{CO}$ emission is due to the extra oxygen content of biodiesel which enhances the complete combustion and leads to the reduction in CO emissions [24-26].

$\mathrm{CO}_{2}$ is one of the gases emitted during combustion of carbon in fuel. There is no universal consensus on the effect of biodiesel on the emission of $\mathrm{CO}_{2}$ from CI engines. Some authors have reported that when a $\mathrm{CI}$ engine runs with biodiesel, the $\mathrm{CO}_{2}$ emission increases as compared to petrol-diesel [7,27,28]. As it is seen in Table 1, Xue et al. [13] have reported that $46 \%$ of the researchers have reported that $\mathrm{CO}_{2}$ emission increases when the engine is running with biodiesel, while $38.5 \%$ of the researchers have reported the reverse trend, and $15.4 \%$ of the researchers have reported that engines running with diesel and biodiesel have similar emissions. The $\mathrm{CO}_{2}$ trend discrepancy may be happening due to the variation of biodiesel feedstock sources, engine types and testing procedures [23].

The incomplete combustion of fossil fuels and fuel evaporation from the open areas are the major sources of hydrocarbons (HC) in the atmosphere. Most reviewed literatures show a sharp decrease (89.5\% as per the Xue et al. [13] review in Table 1) in the THC emissions when substituting conventional diesel fuel with biodiesel fuels in engines due to oxygen, which provides more complete combustion $[26,29,30]$.

The effects of multiple feedstocks on $\mathrm{NO}_{\mathrm{x}}$ emissions [31-34] and $\mathrm{CO}_{2}$ emissions $[11,35,36]$ have been compared by a few researchers using the same engine and testing protocol, using chassis or dyno testing. Recently Pala-En [23] compared emissions from 20\% blends of biodiesel made from four feedstocks (soybean oil, canola oil, waste cooking oil, and animal fat) with emissions from ultra-low sulfur diesel (ULSD) for both real world driving as well as dynamometer tests. They reported that the dynamometer test results showed statistically significant lower emissions of $\mathrm{HC}, \mathrm{CO}$, and $\mathrm{PM}$ from all B20 blends compared to ULSD. For $\mathrm{CO}_{2}$, both on-road testing and dynamometer testing showed no statistically significant difference in emissions among the B20 blends and ULSD. Their $\mathrm{NO}_{\mathrm{x}}$ dynamometer testing showed only B20 from soybean oil to have statistically significant higher emissions.

As the aforementioned review highlights, the studies in emission characteristics of a CI engine running on multiple feedstock and full range of biodiesel blends are fairly inconclusive for $\mathrm{NO}_{\mathrm{x}}$ and $\mathrm{CO}_{2}$. More investigations are required in order to understand the emission characteristics of engines running with biodiesel blends. Based on the review, in this paper two research problems are identified for investigation, which are the effects of biodiesel types on the CI engine emission characteristics and the effects of biodiesel blends on the CI engine emission characteristics. Therefore, the objective of 
this study is to investigate the emission characteristics of a CI engine running with biodiesel blend by varying biodiesel types and blends for heavy duty engine. To investigate the phenomena, experimental investigations were carried out using a heavy duty CI engine (four-cylinder, four-stroke, turbo-charged, water-cooled and direct-injection). In the following section the experimental facilities and test procedures are explained.

\section{Experimental Facilities and Test Procedures}

In this study the combustion characteristics and performance of a CI engine running with biodiesel was investigated using a four-cylinder, four-stroke, turbo-charged, water-cooled and direct-injection CI engine. This particular engine was selected due to its wide application for heavy duty vehicles in Europe. A picture of the engine test and the schematic of the experimental facilities are shown in Figures 1 and 2, respectively.

Figure 1. Experimental engine facilities.

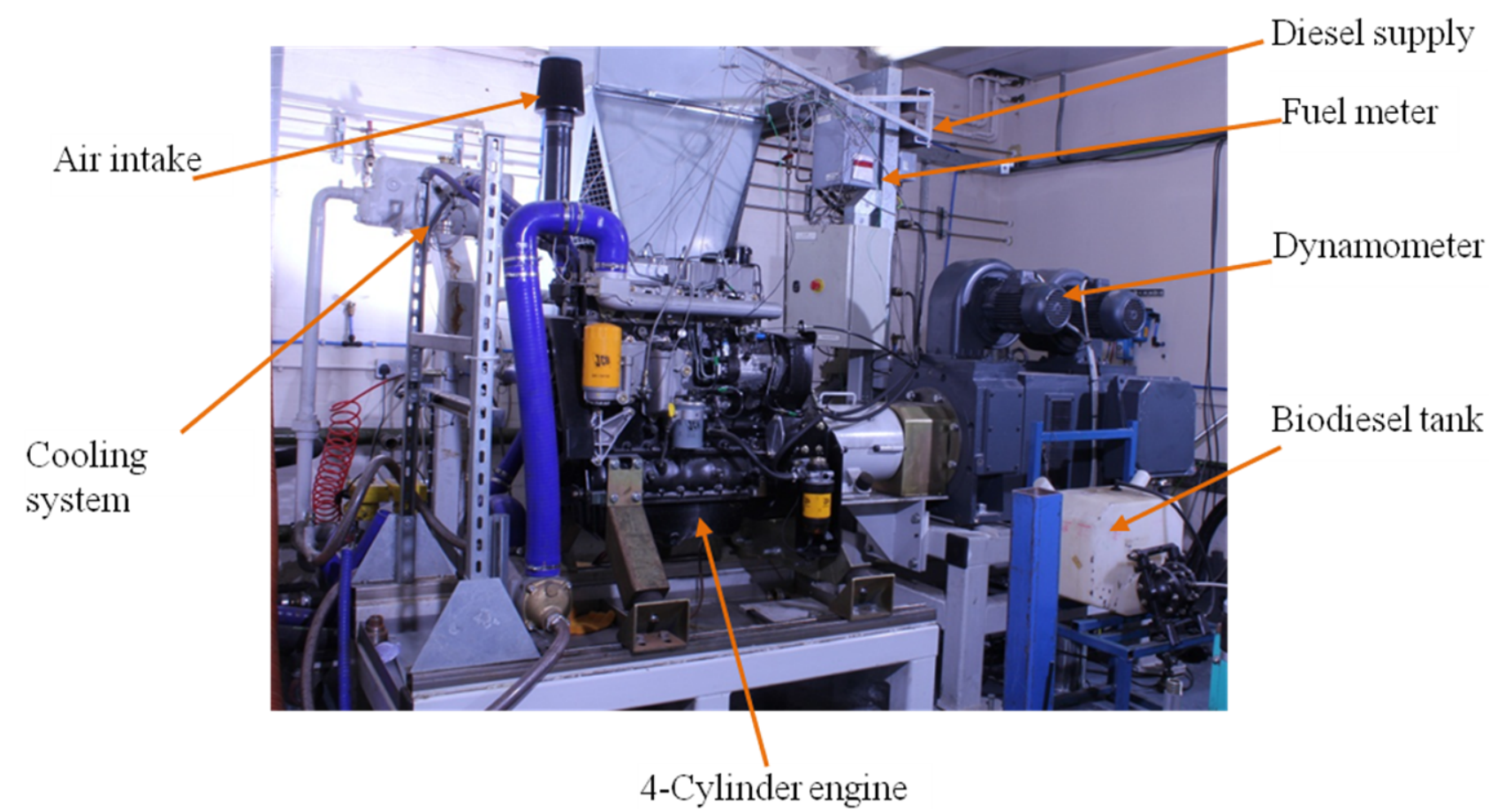

The details of the engine are presented in Table 2. The engine was loaded by a $200 \mathrm{~kW} \mathrm{AC}$ dynamometer 4-Quadrant regenerative drive with motoring and absorbing capability for both steady and transient conditions. The measurements of gaseous emissions were carried out using a HORIBA gas test bench. The measuring range and the analyser types are presented in Table 3 . The sample line of the equipment is connected directly to the exhaust pipe and it is heated to maintain a wall temperature of around $191{ }^{\circ} \mathrm{C}$ and avoid the condensation of hydrocarbons into the line. The insulated line is extended from the exhaust pipe to the equipment's units where the analysers are located.

All emission analysers were set on one bench. However, each emission analyser uses different principles to measure the emission. Oxides of nitrogen are measured on a dry basis, by means of heated chemiluminescent detector (HCLD) with a $\mathrm{NO}_{2} / \mathrm{NO}$ converter. 
Figure 2. Engine test facilities layout [37].

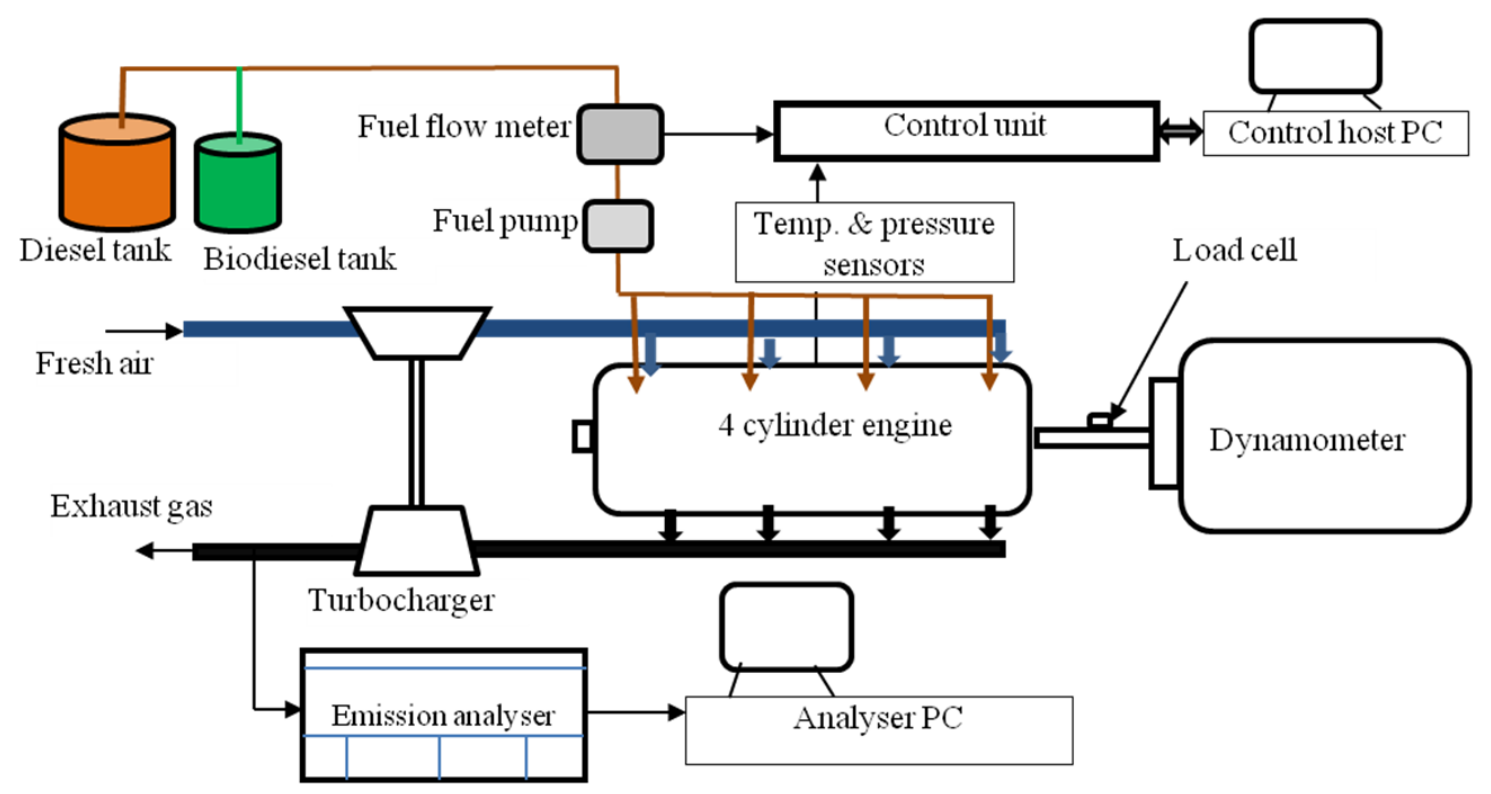

Table 2. Characteristics of the engine.

\begin{tabular}{cc}
\hline Technical parameters & Technical data \\
\hline Engine type & Turbo charged diesel engine \\
Number of cylinders & 4 \\
Bore & $103 \mathrm{~mm}$ \\
Stroke & $132 \mathrm{~mm}$ \\
Compression ratio & $18.3: 1$ \\
Number of valves & 16 \\
Injection system & Direct injection \\
Displacement & 4.399 litre \\
Cooling system & Water \\
Nominal idling speed & $800 \mathrm{rpm}$ \\
Maximum rating gross intermittent & $74.2 @ 2200 \mathrm{rpm}$ \\
Maximum torque & $425 \mathrm{Nm} @ 1300 \mathrm{rpm}$ \\
\hline
\end{tabular}

Table 3. The emission analyser type and measuring range.

\begin{tabular}{cccc}
\hline Emission & Emission analyser type & Measuring range & Accuracy \\
\hline $\mathrm{CO}$ & non-dispersive infrared (NDIR) & $0-2000 \mathrm{ppm}$ & $\pm 2 \%$ \\
$\mathrm{CO}_{2}$ & non-dispersive infrared (NDIR) & $0 \%-100 \%$ & $\pm 2 \%$ \\
$\mathrm{NO}_{\mathrm{x}}$ & heated chemiluminescent detector (HCLD) & $0-5000 \mathrm{ppm}$ & $\pm 2 \%$ \\
$\mathrm{THC}$ & heated flame ionisation detector (HFID) & $0-100 \mathrm{ppm}$ & $\pm 1 \%$ \\
$\mathrm{O}_{2}$ & paramagnetic detector & $0 \%-25 \%$ & $\pm 1 \%$ \\
\hline
\end{tabular}

The carbon monoxide and carbon dioxide were measured with an analyser of the non-dispersive infrared (NDIR) absorption type, whereas a paramagnetic detector was employed for the measurement of $\mathrm{O}_{2}$ concentration in the exhaust flow. The hydrocarbon was measured using the heated flame ionisation detector (HFID). 
On the day prior to the actual test day and also when fuel was changed, a preconditioning procedure at high speed and high load was implemented to purge any of the remaining effects from previous tests in the engine fuel system and also to remove the deposited hydrocarbon on the sample line. During the testing process the engine was run for $10 \mathrm{~min}$ to enable it to come to a steady state before any measurements were carried out. The maximum rated speed and maximum torque of the test engine is specified to be $2200 \mathrm{rpm}$ and $425 \mathrm{Nm}$ respectively. The tests were carried out for a range of engine speeds (from 1000 to $1800 \mathrm{rpm}$ with $200 \mathrm{rpm}$ increments) and at near the maximum engine load (420 Nm).

The biodiesel samples were obtained from a local company. Three common types of commercially available biodiesels (corn oil biodiesel (COB), rapeseed oil biodiesel (ROB), and waste oil biodiesel (WOB)) have been used for analysis. The corn oil biodiesel and rapeseed oil biodiesel were produced from "virgin" oil by the transesterfication process using methanol. The waste oil biodiesel was produced by the same process, although the raw feed was from cooking oil waste. Normal diesel fuel was obtained from a local fuel supplier. The rapeseed was selected for further blend effects investigation due to its wide EU application. Waste oil biodiesel was selected to investigate how the variation of its sources affects the final emission characteristics. Crop oil biodiesel has been considered in this study to characterize the emissions from food source crop oil.

To analyze the dependence of fuel type on the emissions of engines, three neat biodiesels (ROB, $\mathrm{COB}, \mathrm{WOB}$ ) and diesel were used. However, to establish blending and physical properties effects, the blended fuels were prepared by mixing ROB and diesel in different proportions using an in-tank blending method. Blended fuel has a percentage volumetric fraction of $0 \%, 10 \%, 20 \%, 50 \%, 75 \%$ and $100 \%$ of Biodiesel and named B0, B10, B20, B50, B75 and B100 respectively. The blend ratios were set to cover the full possible range of biodiesel application in emission reduction. However, the major car manufacturers have endorsed the application of biodiesel B5 and B20.

The main physical properties such as composition, density, lower heating value (LHV) and viscosity of the rapeseed oil biodiesel were measured according to the official test standards in EU [38]. The blends properties are presented in Table 4.

Table 4. Physical and chemical properties of rapeseed biodiesel and its blends [38].

\begin{tabular}{ccccccccc}
\hline Property & & Accuracy & Diesel (B0) & B10 & B20 & B50 & B75 & B100 \\
\hline \multirow{2}{*}{ Composition (\%) } & $\mathrm{C}$ & - & 87 & 86 & 85 & 82 & 79.5 & 77 \\
\cline { 2 - 8 } & $\mathrm{H}$ & - & 13 & 12.9 & 12.8 & 12.5 & 12.25 & 12 \\
\cline { 2 - 8 } & $\mathrm{O}$ & - & 0 & 1.1 & 2.2 & 5.5 & 8.25 & 11 \\
\hline Density $\left(\mathrm{kg} / \mathrm{m}^{3}\right)$ & $\pm 0.05 \mathrm{~kg} / \mathrm{m}^{3}$ & 853.36 & 859.00 & 865.00 & 871.76 & 872.50 & 879.30 \\
\hline LHV $(\mathrm{MJ} / \mathrm{kg})$ & $\pm 0.01 \mathrm{MJ} / \mathrm{kg}$ & 42.67 & 42.26 & 41.84 & 40.58 & 39.54 & 38.50 \\
\hline Viscosity $\left(\mathrm{mm}^{2} / \mathrm{s}\right)$ & $\pm 0.02 \mathrm{~mm}^{2} / \mathrm{s}$ & 3.55 & 3.91 & 4.28 & 4.68 & 4.74 & 5.13 \\
\hline
\end{tabular}

\section{Results and Discussion}

One of the benefits of using biodiesel as an alternative fuel is its capability of reducing the pollutant emissions to the environment. In this section the emission characteristics of the test $\mathrm{CI}$ engine running with diesel, ROB, COB and WOB have been investigated. In addition, the effects of biodiesel content on the emission characteristics have been investigated and reported. The main exhaust emissions analysed in the present investigation are $\mathrm{CO}_{2}, \mathrm{CO}, \mathrm{NO}_{\mathrm{x}}$ and $\mathrm{THC}$. 


\subsection{Effects of Biodiesel Content on Engine Emissions Parameters}

The $\mathrm{CO}_{2}$ emission values of the $\mathrm{CI}$ engine running on $\mathrm{ROB}, \mathrm{COB}$, WOB and diesel fuel at a $420 \mathrm{Nm}$ load and at a range of engine speeds are shown in Figure 3. The ROB, COB, WOB and diesel resulted in maximum $\mathrm{CO}_{2}$ emissions of $4.85 \%, 4.74 \%, 4.80 \%$ and $6 \%$, respectively. As seen in Figure $3 \mathrm{~b}$, the $\mathrm{CI}$ engine running on biodiesel emitted lower $\mathrm{CO}_{2}$ than when running on diesel by an average of $17 \%$. It is noticed that the engine running with the WOB resulted in inconsistent emission at lower engine speed. Comparing the three biodiesels ROB, COB and WOB, it can be seen that each fuel emitted almost equal amounts of $\mathrm{CO}_{2}$. Similar results have been reported earlier [13,27]. However, some authors have reported that the engine fuelled by biodiesel fuels emit higher $\mathrm{CO}_{2}[27,39,40]$. Some investigations in the past have also reported that $\mathrm{CO}_{2}$ emissions remain unchanged on changing fuel from diesel to biodiesel [24,41].

Figure 3. (a) Variation of $\mathrm{CO}_{2}$ emission of $\mathrm{CI}$ engine running with $\mathrm{ROB}, \mathrm{COB}, \mathrm{WOB}$ and diesel at a load of $420 \mathrm{Nm}$; (b) $\mathrm{CO}_{2}$ emission reductions in percentage comparing biodiesel (ROB, COB, WOB) with diesel at $420 \mathrm{Nm}$.

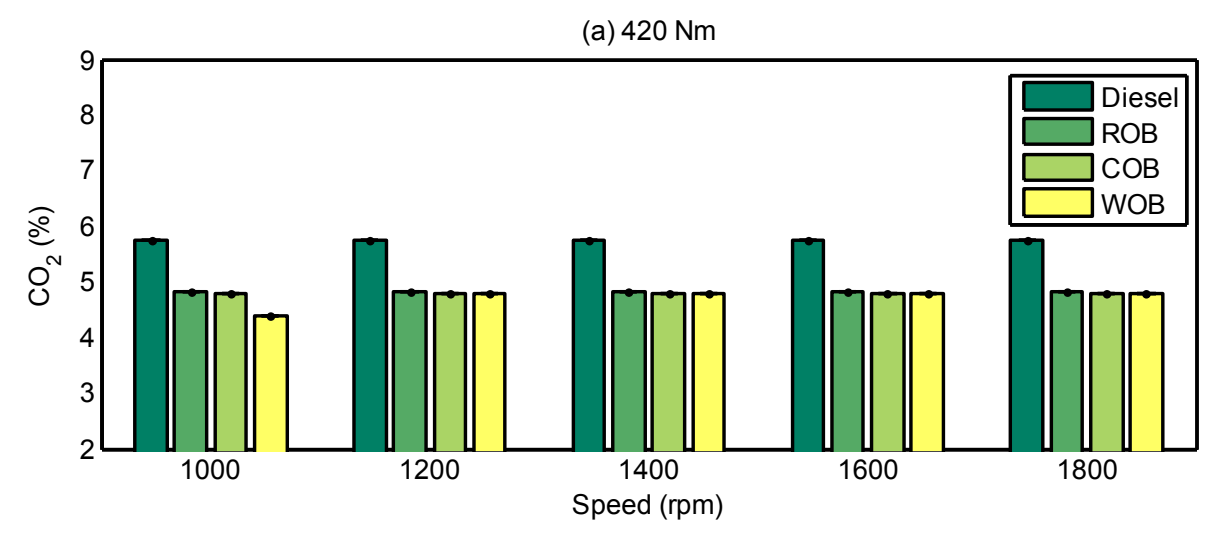

(b) $420 \mathrm{Nm}$

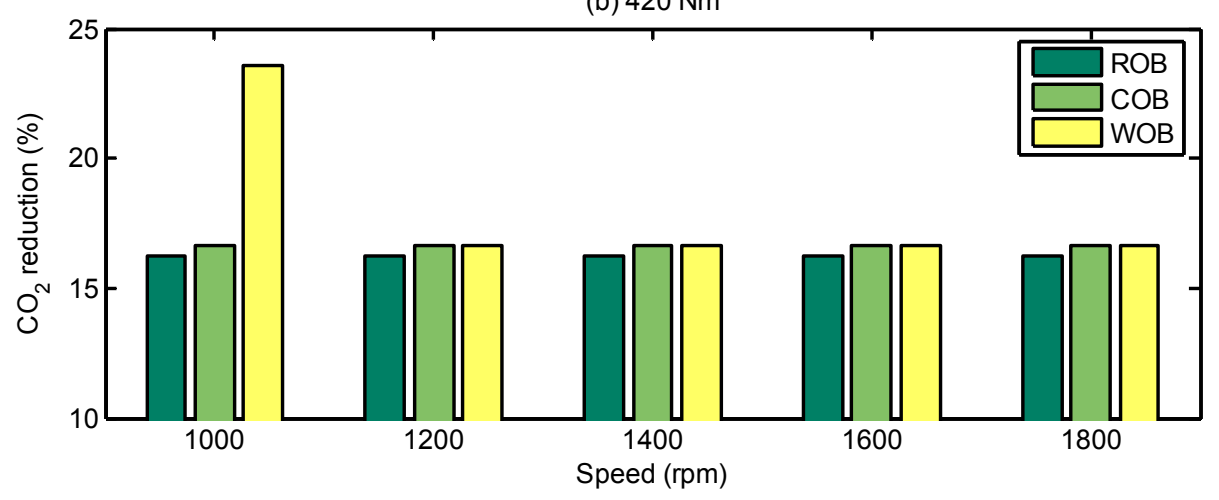

Figure $4 \mathrm{a}$ depicts the $\mathrm{NO}_{\mathrm{x}}$ emissions of the test $\mathrm{CI}$ engine running on the ROB, COB, WOB and diesel. The corresponding maximum engine emission values were observed to be $1350 \mathrm{ppm}$, $1355 \mathrm{ppm}, 1340 \mathrm{ppm}$ and $1040 \mathrm{ppm}$, respectively, at a load of $420 \mathrm{Nm}$ over the engine speed range of 1000-1800 rpm. From Figure 4, it is apparent that the $\mathrm{NO}_{\mathrm{x}}$ emissions increased with the increase in the engine speed. This can be primarily due to an increase in volumetric efficiency and gas flow motion within the engine cylinder under higher engine speeds and higher load operating conditions, which led to a faster mixing between fuel and air and hence shorter ignition delay [11,42]. The ROB, COB and 
WOB resulted in higher $\mathrm{NO}_{\mathrm{x}}$ emissions than the normal diesel by up to $27 \%$, as shown in Figure $4 \mathrm{~b}$. This phenomenon is due to the resulting advanced injection because of the influence of the physical properties of biodiesel, such as viscosity, density, compressibility and sound velocity [13,19,20]. Some researchers argue that the main cause of $\mathrm{NO}_{\mathrm{x}}$ increase with biodiesel use is the increased cetane number $[20,43]$ which leads to an advanced combustion by shortening the ignition delay and the higher availability of oxygen $[12,13,43]$ which in turn promotes $\mathrm{NO}_{\mathrm{x}}$ formation. However, when comparing the $\mathrm{NO}_{\mathrm{x}}$ emissions of $\mathrm{ROB}, \mathrm{COB}$ and WOB, no significant differences in the $\mathrm{NO}_{\mathrm{x}}$ emissions are apparent. The standard deviations values have been indicated with the mean value of the $\mathrm{NO}_{\mathrm{x}}$ emission for each condition, as it shown in Figure 4a. The maximum standard deviation was computed to be $15 \mathrm{ppm}$ at $1800 \mathrm{rpm}$.

Figure 4. (a) Variation of $\mathrm{NO}_{\mathrm{x}}$ emission of $\mathrm{CI}$ engine running with $\mathrm{ROB}, \mathrm{COB}, \mathrm{WOB}$ and diesel at a load of $420 \mathrm{Nm}$; (b) $\mathrm{NO}_{\mathrm{x}}$ emission reductions in percentage comparing biodiesel (ROB, COB, WOB) with diesel at $420 \mathrm{Nm}$.

(a) $420 \mathrm{Nm}$

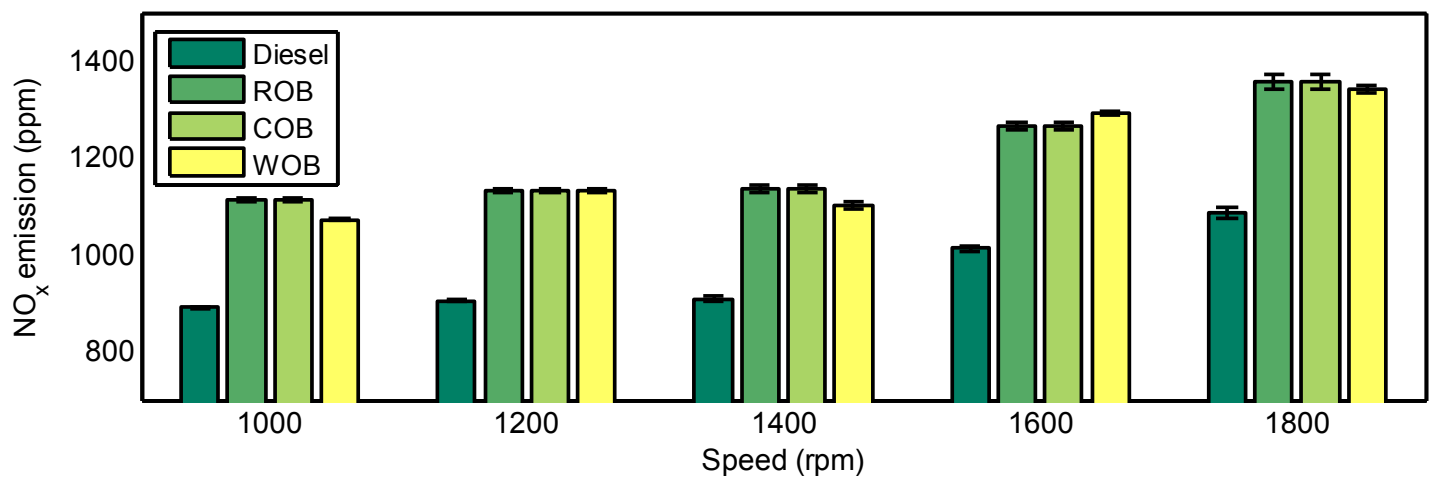

(b) $420 \mathrm{Nm}$

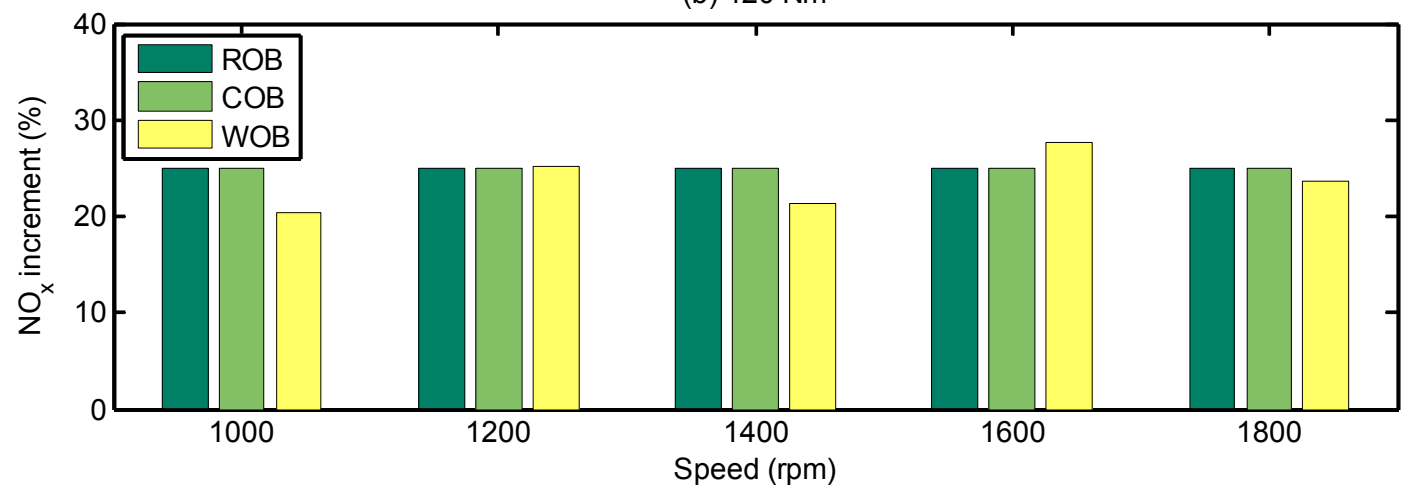

The graph shown in Figure 5a depicts the THC emissions of the CI engine running with ROB, $\mathrm{COB}$, WOB and diesel at a load of $420 \mathrm{Nm}$ over a speed range of 1000-1800 rpm. From the figure, it can be seen that the THC emission decreases with an increase in engine speed. This may be due to better air-fuel mixing process and/or the increased fuel/air ratio at higher engine speeds $[19,44,45]$.

The two "virgin" biodiesels i.e., ROB and $\mathrm{COB}$ did not show any significant differences in THC emission values. However, the engine running on these two biodiesels has a reduced THC emission value by $28 \%$, as compared to the neat diesel, as shown in Figure $5 \mathrm{~b}$. The WOB use also reduces the THC; however the reduction was only about $5 \%$ as compared to diesel. The standard deviations of the 
measurements are indicated along with the mean value of the THC emission for each condition in the figure. The maximum standard deviation has been computed to be $2 \mathrm{ppm}$ at $1800 \mathrm{rpm}$.

Figure 5. (a) Variation of THC emission of $\mathrm{CI}$ engine running with $\mathrm{ROB}, \mathrm{COB}, \mathrm{WOB}$ and diesel at a load of $420 \mathrm{Nm}$; (b) THC emission reductions in percentage comparing biodiesel (ROB, COB, WOB) with diesel at $420 \mathrm{Nm}$.

(a) $420 \mathrm{Nm}$

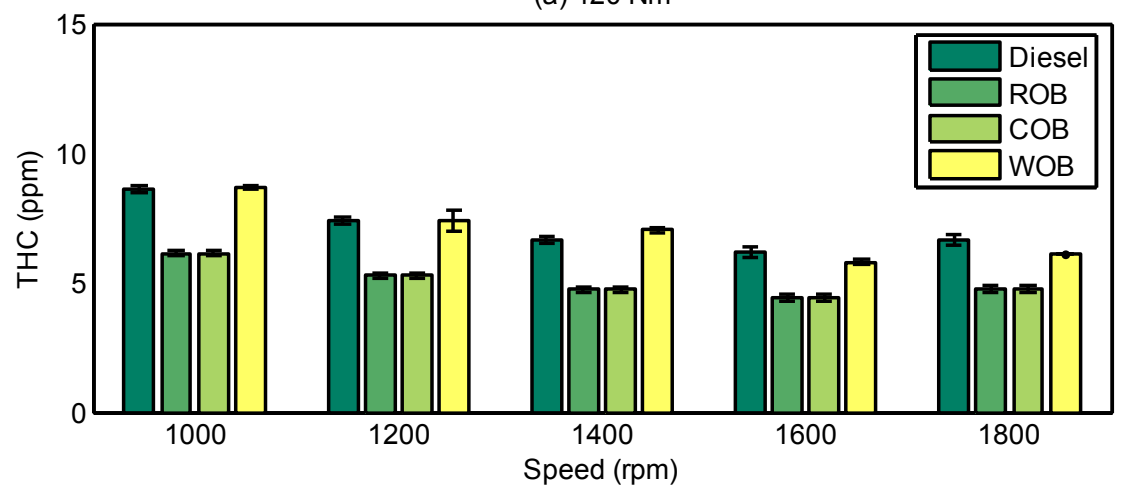

(b) $420 \mathrm{Nm}$

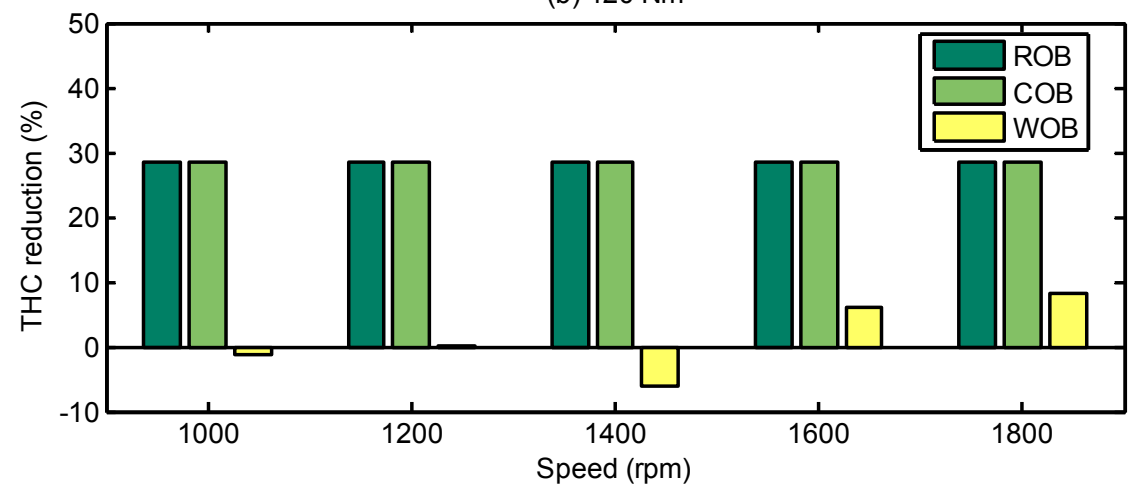

Figure 6a presents the $\mathrm{CO}$ emissions for the engine running with $\mathrm{ROB}, \mathrm{COB}, \mathrm{WOB}$ and diesel at a load of $420 \mathrm{Nm}$ over an engine speed range of 1000-1800 rpm. In Figure 6, a clear trend can be seen that $\mathrm{CO}$ emissions decrease with increasing engine speeds. This is because when the engine speed increases, the air-fuel mixing process may become more intensive and a higher fuel/air equivalence may have resulted in enhancing the conversion of CO to CO2 $[19,24,46]$. The CO emission of the neat biodiesel was lower than that of the diesel by $28 \%$, as indicated in Figure $6 \mathrm{~b}$. However, comparing $\mathrm{ROB}, \mathrm{COB}$ and $\mathrm{WOB}$, the three neat biodiesels did not show any significant differences in $\mathrm{CO}$ emission. The standard deviations of the measurements are indicated with the mean value of the $\mathrm{CO}$ emission for each condition, having a maximum standard deviation of $3.5 \mathrm{ppm}$.

The above results have clearly indicated that the biodiesel sources do not affect the engine emissions and as long as physical properties are similar we can expect same emissions characteristics from the engine. The next section is therefore focused on investigation with one of the biodiesel used (ROB) for detailed analysis and in this investigation the fuel properties have been varied by blending diesel with biodiesel in different proportions. 
Figure 6. (a) Variation of $\mathrm{CO}$ emission of $\mathrm{CI}$ engine running with $\mathrm{ROB}, \mathrm{COB}$, WOB and diesel at a load of $420 \mathrm{Nm}$; (b) $\mathrm{CO}$ emission reductions in percentage comparing biodiesel (ROB, COB, WOB) with diesel at $420 \mathrm{Nm}$.

(a) $420 \mathrm{Nm}$

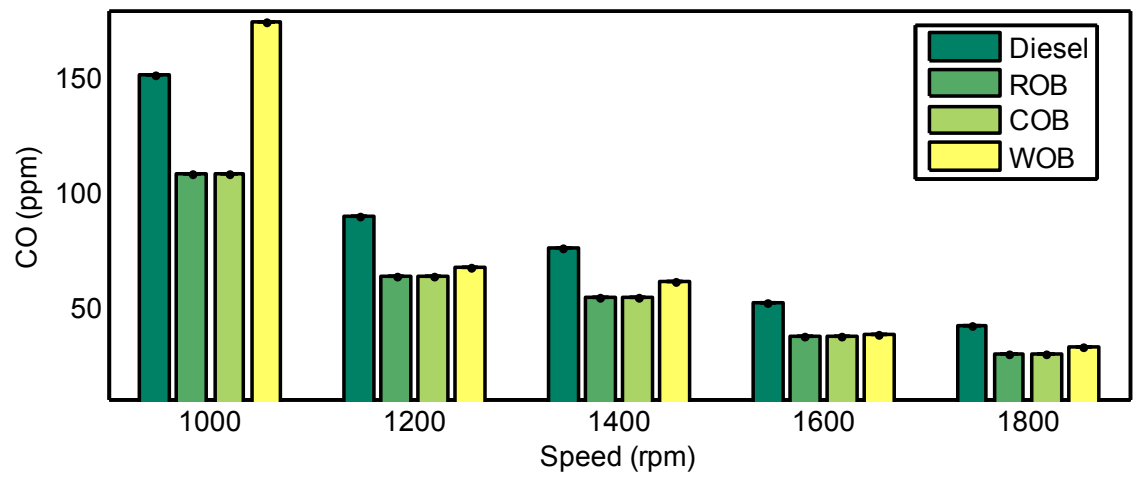

(b) $420 \mathrm{Nm}$

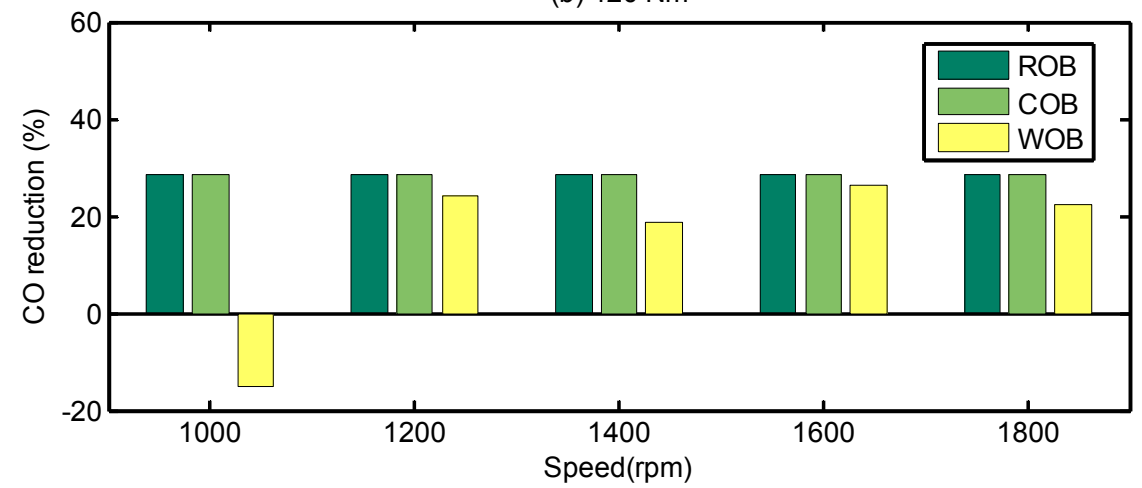

\subsection{Effects of Biodiesel Blend Fraction on Engine Emissions Parameters}

Experimental emission results obtained from the tests on a CI engine fuelled with rapeseed biodiesel blends running at a range of engine speeds and at $420 \mathrm{Nm}$ load, are shown in Figure 7 to Figure 10. The higher load was selected for emissions investigation due to its sensitivity for emissions. Both the real values of the emissions and the percentage change of the emission over a wide range of conditions are reported. Figure 7a provides the $\mathrm{CO}_{2}$ emissions of $\mathrm{CI}$ engines over a range of engine speeds. It can be seen that the $\mathrm{CO}_{2}$ emissions reduce significantly with increases in the engine speeds. The $\mathrm{CI}$ engine's $\mathrm{CO}_{2}$ emissions corresponding to neat diesel and various biodiesel blends (B10, B20, $\mathrm{B} 50$ and $\mathrm{B} 100$ ) have been compared and resulted in a reduction change in $\mathrm{CO}_{2}$ emission as shown in Figure $7 \mathrm{~b}$. It shows that the $\mathrm{CI}$ engine's $\mathrm{CO}_{2}$ emission reduced by $7 \%, 27 \%, 40 \%$ and $30 \%$ corresponding to $\mathrm{B} 10, \mathrm{~B} 20, \mathrm{~B} 50$ and $\mathrm{B} 100$ as compared to diesel value respectively. The $\mathrm{CO}_{2}$ emission by B50 shows the lowest reduction. This is not the normal trend in most of the previous report. It needs a further investigation.

The engine fuelled with $\mathrm{B} 50$ resulted in the maximum reduction of $\mathrm{CO}_{2}$ emission among the different blends used, which is different from that which previous researchers recommended with optimum biodiesel blends of $20 \%$. The engine fuelled with biodiesel emitted lower $\mathrm{CO}_{2}$ emissions than diesel due to the lower carbon to hydrogen ratio [13,42]. The carbon content of biodiesel was $77 \%$, whilst for diesel it was $87 \%$, as can be seen in Table 4 . 
Figure 7. (a) Variation of $\mathrm{CO}_{2}$ emissions with engine speed for $\mathrm{CI}$ engine running with biodiesel blends at a load of $420 \mathrm{Nm}$; (b) $\mathrm{CO}_{2}$ emission reductions due to biodiesel blends (B10, B20, B50, B100) comparing with diesel at $420 \mathrm{Nm}$.

(a) $420 \mathrm{Nm}$

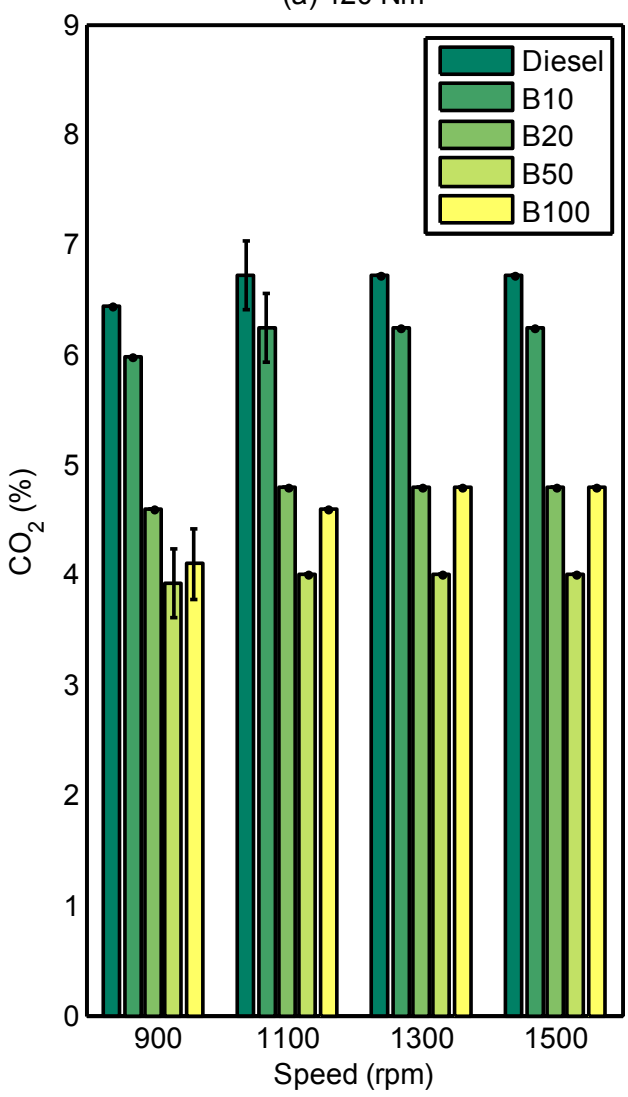

(b) $420 \mathrm{Nm}$

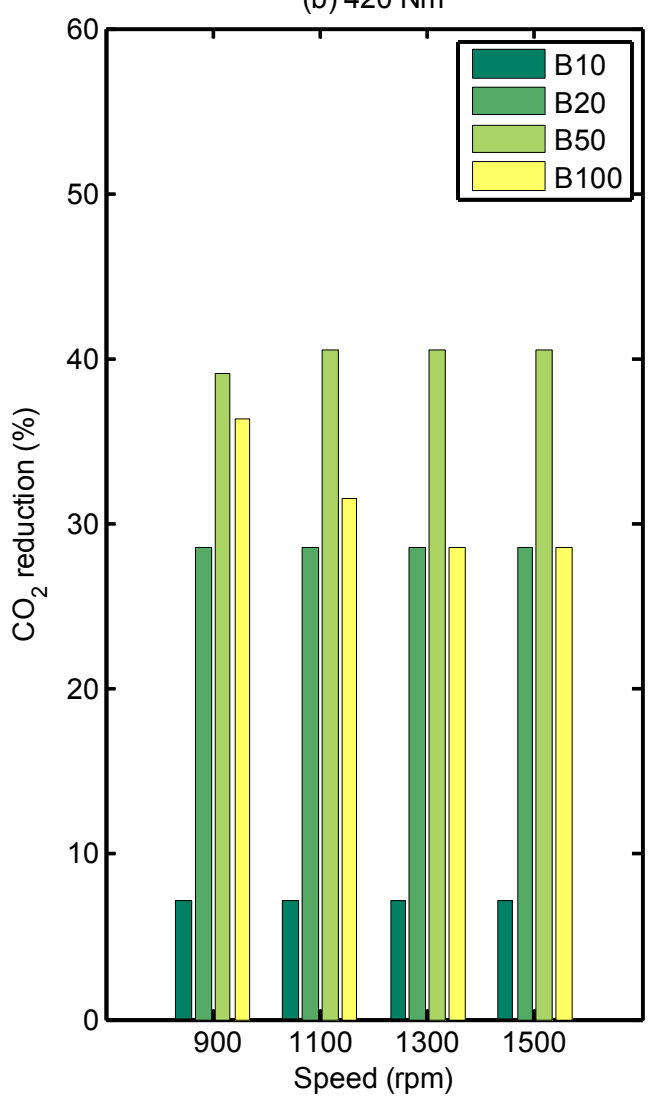

Figure 8a compares the $\mathrm{NO}_{\mathrm{x}}$ emissions from the test CI engine fuelled with diesel, B10, B20, B50 and $\mathrm{B} 100$, at a load of $420 \mathrm{Nm}$ over a wide range of engine speeds. It can be seen that the $\mathrm{NO}_{\mathrm{x}}$ emission increases with an increase in engine speed as discussed in Section 3.1. It can further be seen that a higher percentage of biodiesel blend emits higher values of $\mathrm{NO}_{\mathrm{x}}$ emissions, as shown in Figure $8 \mathrm{~b}$.

The use of biodiesel blend $\mathrm{B} 10$ increased the $\mathrm{NO}_{\mathrm{x}}$ emissions by $10 \%$, whilst the neat biodiesel increased the emission value by up to $37 \%$ at $1100 \mathrm{rpm}$, both as compared to the emission resulting from the use of diesel. Other researchers have also reported that $\mathrm{NO}_{\mathrm{x}}$ emissions increased in a similar range $[47,48]$ if biodiesel is used as fuel as compared to diesel. The main reasons for higher $\mathrm{NO}_{\mathrm{x}}$ emissions with an increase in biodiesel content could be due to the advance injection and advance combustion, as a result of its higher viscosity $[12,13,19,43]$, higher oxygen content which enhances $\mathrm{NO}_{\mathrm{x}}$ formation $[12,13,44]$ and a higher cetane number which shortens ignition delay and advances the combustion [20].

The THC emissions of the test $\mathrm{CI}$ engine running on diesel and biodiesel blends at various engine speeds and at $420 \mathrm{Nm}$ load are depicted in Figure 9a. It can be noticed that the biodiesel blends emitted lower THC emissions as compared to diesel. However, a trend discrepancy is seen at an engine speed of $1100 \mathrm{rpm}$. The THC reduction reached $45 \%$ at $1300 \mathrm{rpm}$ engine speed for B100. Previous researchers have also reported that the engine fuelled with biodiesel could reduce the THC up to $67 \%[26,30,31]$. The reduction of the THC in CI engines running on biodiesel can be explained on the 
basis of a lower content of carbon to hydrogen ratio than the normal diesel and presence of up to $11 \%$ oxygen in its molecular structure.

Figure 8. (a) Variation of $\mathrm{NO}_{\mathrm{x}}$ emissions with engine speed for $\mathrm{CI}$ engine running with biodiesel blends at a load of $420 \mathrm{Nm}$; (b) $\mathrm{NO}_{\mathrm{x}}$ emission reductions due to biodiesel blends (B10, B20, B50, B100) comparing with diesel at $420 \mathrm{Nm}$.
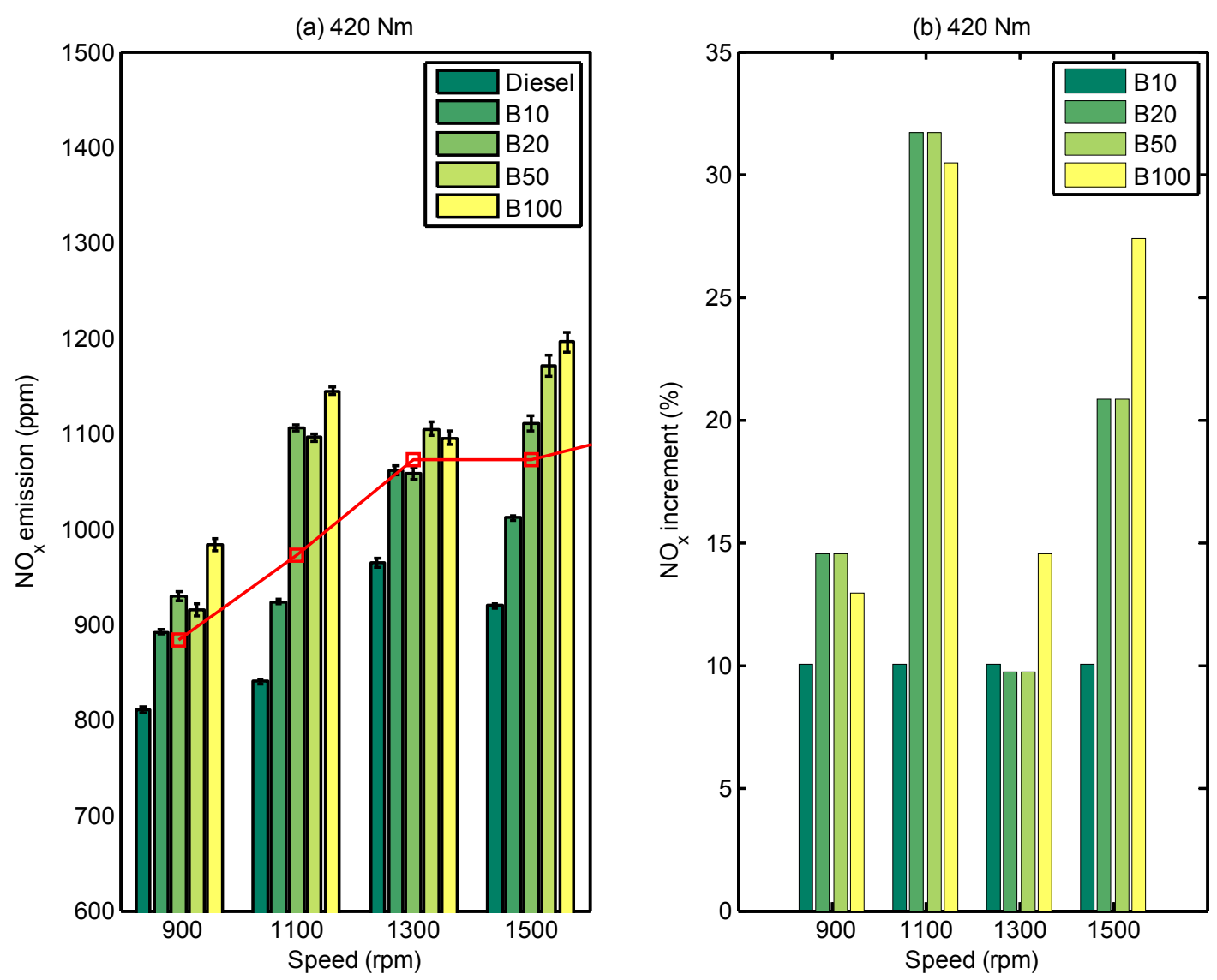

The CO emission characteristics of the CI engine fuelled by the diesel and rapeseed biodiesel blends at the maximum engine load and at various speed conditions are shown in Figure 10. All the fuels used produced a higher amount of $\mathrm{CO}$ emissions at lower speeds and emitted less $\mathrm{CO}$ at higher engine speeds. The effect of engine speed on $\mathrm{CO}$ emission is discussed in Section 3.1. It can be also seen when the biodiesel content increases, the $\mathrm{CO}$ emission is decreasing by an average of up to $25 \%$.

Krahl et al. [30] and Raheman and Phadatre [48] reported that the engine running on biodiesel reduced the $\mathrm{CO}$ emission by $50 \%$ and $73 \%-94 \%$, respectively. The main reason for reduction of $\mathrm{CO}$ emissions is the availability of oxygen in the biodiesel for better combustion. The extra oxygen in the biodiesel promotes complete combustion of fuel and thus results in the reduction of $\mathrm{CO}$ emissions [11,14,16]. 
Figure 9. (a) Variation of THC emissions with engine speed for CI engine running with biodiesel blends at a load of $420 \mathrm{Nm}$; (b) THC emission reductions due to biodiesel blends (B10, B20, B50, B100) comparing with diesel at $420 \mathrm{Nm}$.
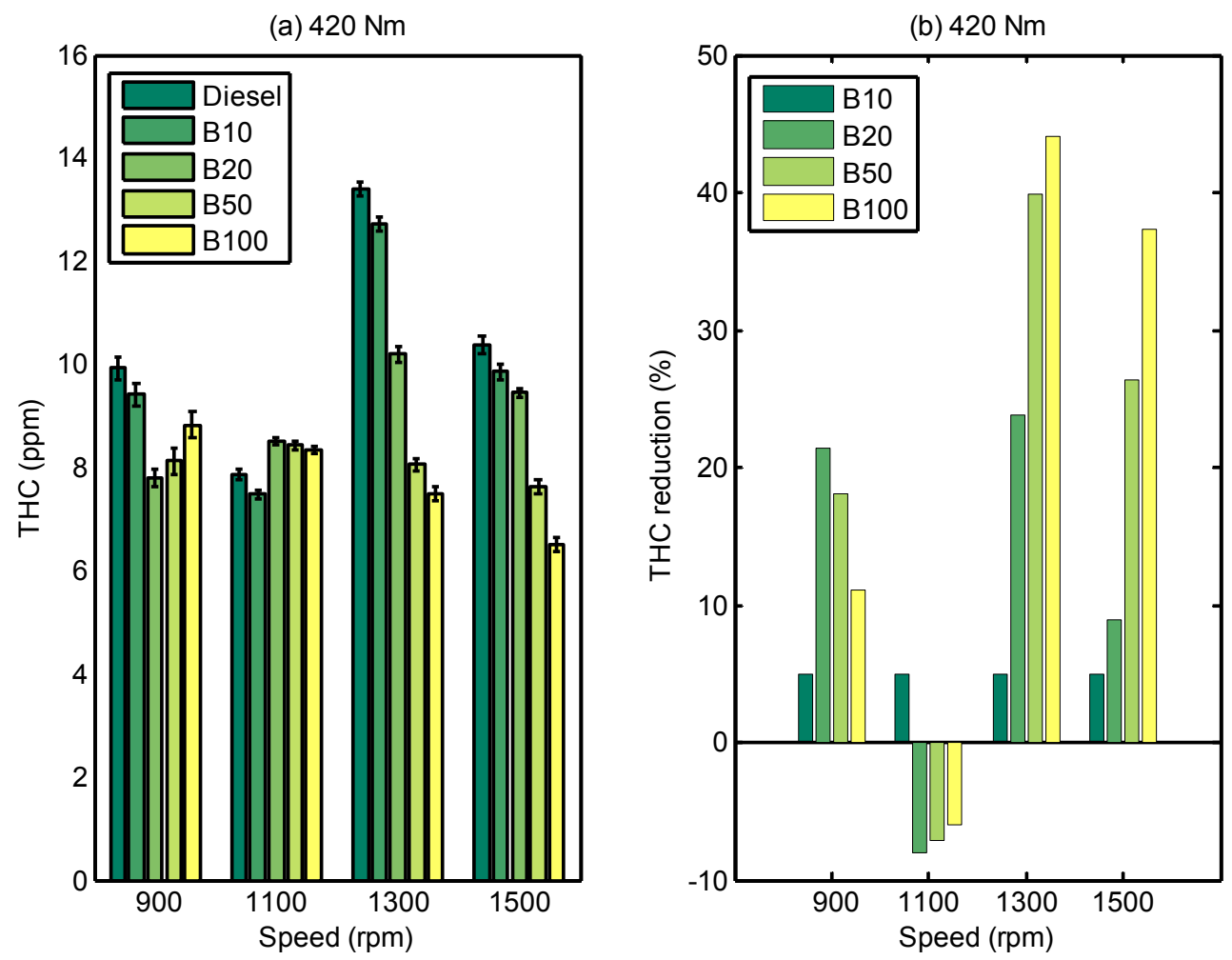

Figure 10. (a) Variation of $\mathrm{CO}$ emissions with engine speed for $\mathrm{CI}$ engine running with biodiesel blends at a load of $420 \mathrm{Nm}$; (b) $\mathrm{CO}$ emission reductions due to biodiesel blends (B10, B20, B50, B100) comparing with diesel at $420 \mathrm{Nm}$.

(a) $420 \mathrm{Nm}$

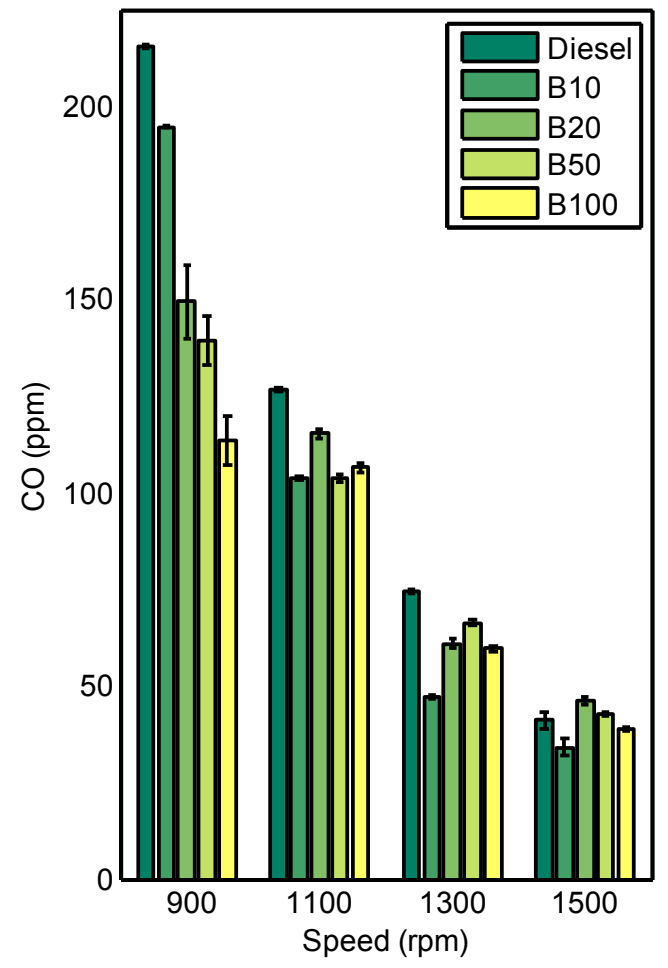

(b) $420 \mathrm{Nm}$

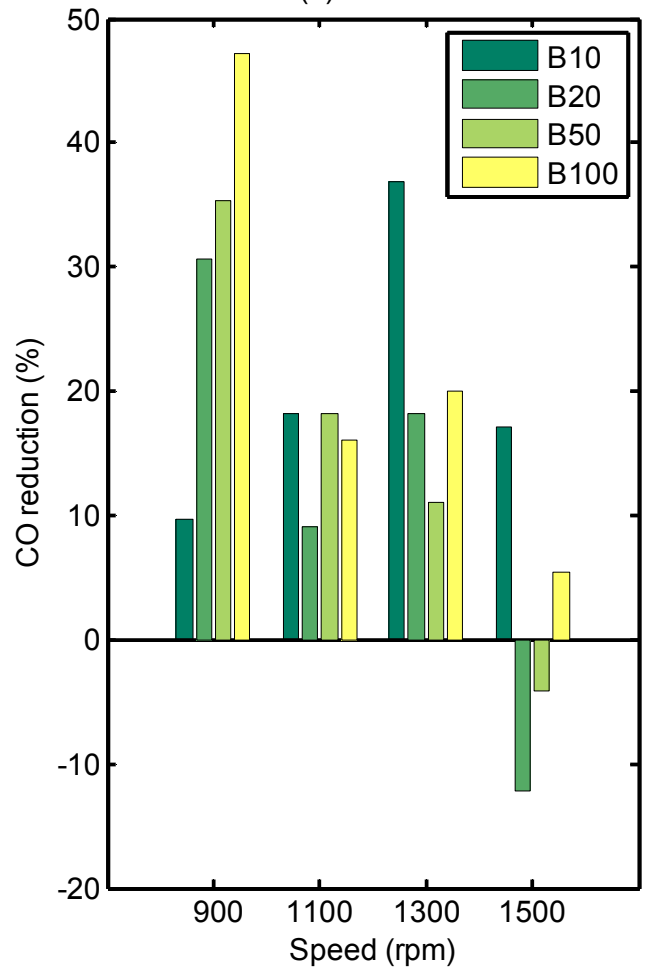




\section{Conclusions}

The effects of biodiesel types and blend fraction values on the $\mathrm{CI}$ engine's emissions $\left(\mathrm{CO}_{2}, \mathrm{CO}\right.$, $\mathrm{NO}_{\mathrm{x}}$ and $\mathrm{THC}$ ) characteristics were investigated in detail for steady state operation conditions. The following conclusions are drawn for this specific fuel and engine configuration:

1. The source of biodiesel does not show a significant effect on the CI engine's emissions $\left(\mathrm{CO}_{2}\right.$, $\mathrm{CO}, \mathrm{NO}_{\mathrm{x}}$ and $\mathrm{THC}$ ) as long as the fuel physical (density, viscosity and lower heating value) and chemical (molecular composition) properties remain same.

2. The emission analyses of the $\mathrm{CI}$ engine running with biodiesel highlights a significant reduction in $\mathrm{CO}_{2}, \mathrm{CO}$ and $\mathrm{THC}$ emission under working engine operation conditions. It is also found that when the biodiesel content increases a further reduction in emissions is observed, except for $\mathrm{CO}$, where $\mathrm{B} 20$ and $\mathrm{B} 50$ produced lower results. This emission reduction is most likely a result of the oxygen content in biodiesel and the low carbon hydrogen ratio.

3. For all biodiesel contents the $\mathrm{NO}_{\mathrm{x}}$ emission increases for all operating conditions of the $\mathrm{CI}$ engine. This increase may be explained by the higher oxygen content present in biodiesel and the advanced injection characteristics.

\section{Acknowledgments}

The authors would like to thank the University of Huddersfield for giving the fee-waiver scholarship for Belachew Tesfa's $\mathrm{PhD}$ research.

\section{Conflicts of Interest}

The authors declare no conflict of interest.

\section{References}

1. Nabi, M.N.; Hustad, J.E. Influence of biodiesel addition to Fischer-Tropsch fuel on diesel engine performance and exhaust emissions. Energy Fuels 2010, 24, 2868-2874.

2. Tauzia, X.; Maiboom, A.; Shah, S.R. Experimental study of inlet manifold water injection on combustion and emissions of an automotive direct injection diesel engine. Energy 2010, 35, 3628-3639.

3. Bayraktar, H. Experimental and theoretical investigation of using gasoline-ethanol blends in spark-ignition engines. Renew. Energy 2005, 30, 1733-1747.

4. MacKenzie, J.J. Oil as a finite resource. Nonrenew. Resour. 1998, 7, 97-100.

5. Ramadhas, A.S.; Muraleedharan, C.; Jayaraj, S. Performance and emission evaluation of a diesel engine fueled with methyl esters of rubber seed oil. Renew. Energy 2005, 30, 1789-1800.

6. Hammond, G.P.; Kallu, S.; McManus, M.C. Development of biofuels for the UK automotive market. Appl. Energy 2008, 85, 506-515.

7. Lapuerta, M.; Armas, O.; Ballesteros, R.; Fernandez, J. Diesel emissions from biofuels derived from Spanish potential vegetable oils. Fuel 2005, 84, 773-780. 
8. Durbin, T.D.; Collins, J.R.; Norbeck, J.M.; Smith, M.R. Effects of biodiesel, biodiesel blends, and a synthetic diesel on emissions from light heavy-duty diesel vehicles. Environ. Sci. Technol. 2000, 34, 349-355.

9. Puppan, D. Environmeental Evaluation of Biofules. Available online: http://www.pp.bme.hu/ so/2002_1/pdf/so2002_1_08.pdf (accessed on 16 June 2008).

10. Dorado, M.P.; Ballesteros, E.; Arnal, J.M.; Gomez, J.; Lopez, F.J. Exhaust emissions from a Diesel engine fueled with transesterified waste olive oil. Fuel 2003, 82, 1311-1315.

11. Utlu, Z.; Kocak, M.S. The effect of biodiesel fuel obtained from waste frying oil on direct injection diesel engine performance and exhaust emissions. Renew. Energy 2008, 33, 1936-1941.

12. Lapuerta, M.; Armas, O.; Rodríguez-Fernández, J. Effect of biodiesel fuels on diesel engine emissions. Prog. Energy Combust. Sci. 2008, 34, 198-223.

13. Xue, J.; Grift, T.E.; Hansen, A.C. Effect of biodiesel on engine performances and emissions. Renew. Sustain. Energy Rev. 2011, 15, 1098-1116.

14. Bhale, P.V.; Deshpande, N.V.; Thombre, S.B. Improving the low temperature properties of biodiesel fuel. Renew. Energy 2009, 34, 794-800.

15. Krisnangkura, K. Estimation of heat of combustion of triglycerides and fatty acid methyl esters. J. Am. Oil Chem. Soc. 1991, 68, 56-58.

16. Carraretto, C.; Macor, A.; Mirandola, A.; Stoppato, A.; Tonon, S. Biodiesel as alternative fuel: Experimental analysis and energetic evaluations. Energy 2004, 29, 2195-2211.

17. Murillo, S.; Míguez, J.L.; Porteiro, J., Granada, E.; Morán, J.C. Performance and exhaust emissions in the use of biodiesel in outboard diesel engines. Fuel 2007, 86, 1765-1771.

18. Cardone, M.; Prati, M.V.; Rocco, V.; Seggiani, M.; Senatore, A.; Vitolo, S. Brassica carinata as an alternative oil crop for the production of biodiesel in Italy: Engine performance and regulated and unregulated exhaust emissions. Environ. Sci. Technol. 2002, 36, 4656-4662.

19. Yamane, K.; Ueta, A.; Shimamoto, Y. Influence of physical and chemical properties of biodiesel fuels on injection, combustin and exhaust emission characteristics in a direct injection compression ignition engine. Int. J. Engine Res. 2001, 2, 249-261.

20. Monyem, A.; Van Gerpen, J.H. The effect of biodiesel oxidation on engine performance and emissions. Biomass Bioenergy 2001, 20, 317-325.

21. Qi, D.H., Geng, L.M.; Chen, H.; Bian, Y.Z.; Liu, J.; Ren, X.C. Combustion and performance evaluation of a diesel engine fueled with biodiesel produced from soybean crude oil. Renew. Energy 2009, 34, 2706-2713.

22. Armas, O.; Yehliu, K.; Boehman, A.L. Effect of alternative fuels on exhaust emissions during diesel engine operation with matched combustion phasing. Fuel 2010, 89, 438-456.

23. Pala-En, N.; Sattler, M.; Dennis, B.H.; Chen Victoria, C.P.; Muncrief, R.L. On-road measurement of $\mathrm{NO}_{\mathrm{x}}$ and $\mathrm{CO}_{2}$ emissions from biodiesel produced from different feedstocks. J. Environ. Prot. 2013, 4, 74-82.

24. Usta, N.; Öztürk, E.; Can, Ö.; Conkur, E.S.; Nas, S.; Çon, A.H.; Can, A.Ç.; Topcu, M. Combustion of biodiesel fuel produced from hazelnut soapstock/waste sunflower oil mixture in a diesel engine. Energy Convers. Manag. 2005, 46, 741-755.

25. Al-Widyan, M.I.; Tashtoush, G.; Abu-Qudais, M. Utilization of ethyl ester of waste vegetable oils as fuel in diesel engines. Fuel Process. Technol. 2002, 76, 91-103. 
26. Puhan, S.; Vedaraman, N.; Sankaranarayanan, G.; Ram, B.V.B. Performance and emission study of Mahua oil (madhuca indica oil) ethyl ester in a 4-stroke natural aspirated direct injection diesel engine. Renew. Energy 2005, 30, 1269-1278.

27. Canakci, M. Combustion characteristics of a turbocharged DI compression ignition engine fueled with petroleum diesel fuels and biodiesel. Bioresour. Technol. 2007, 98, 1167-1175.

28. Kaplan, C.; Arslan, R.; Surmen, A. Performance characteristics of sunflower methyl esters as biodiesel. Energy Sources Part A Recovery Util. Environ. Eff. 2006, 28, 751-755.

29. Krahl, J.; Munack, A.; Bahadir, M.; Schumacher, L.; Elser, N. Review: Utilization of Rapeseed Oil, Rapeseed Oil Methyl Ester or Diesel Fuel: Exhaust Gas Emissions and Estimation of Environmental Effects. In Proceedings of the International Fall Fuels and Lubricant Meeting, San Antonio, TX, USA, 1996; doi:10.4271/962096.

30. Nabi, M.N.; Akhter, M.S.; Zaglul Shahadat, M.M. Improvement of engine emissions with conventional diesel fuel and diesel-biodiesel blends. Bioresour. Technol. 2006, 97, 372-378.

31. Karavalakis, G.; Stournas, S.; Bakeas, E. Light vehicle regulated and unregulated emissions from different biodiesels. Sci. Total Environ. 2009, 407, 3338-3346.

32. Peterson, C.L.; Taberski, J.S.; Thompson, J.C.; Chase, C.L. The effect of biodiesel feedstock on regulated emissions in chassis dynamometer tests of a pickup truck. Trans. Am. Soc. Agric. Eng. 2000, 43, 1371-1381.

33. Rakopoulous, C.D.; Antonopoulos, K.A.; Rakopoulos, D.C.; Hountalas, D.T.; Giakoumis, E.G. Comparative performance and emissions study of a direct injection diesel engine using blends of diesel fuel with vegetable oils or bio-diesels of various origins. Energy Convers. Manag. 2006, 47, 3272-3287.

34. Muncrief, R.L.; Rooks, C.W.; Cruz, M.; Michael, P.H. Combining biodiesel and exhaust gas recirculation for reduction in $\mathrm{NO}_{\mathrm{x}}$ and particulate emissions. Energy Fuels 2008, 22, 1285-1296.

35. Fontaras, G.; Karavalakis, G.; Kousoulidou, M.; Tzamkiozis, T.; Ntziachristos, L.; Bakeas, E.; Stournas, S.; Samaras, Z. Effects of biodiesel on passenger car fuel consumption, regulated and non-regulated pollutant emissions over legislated and real-world driving cycles. Fuel 2009, 88, 1608-1617.

36. Lin, Y.; Wu, Y.G.; Chang, C. Combustion characteristics of waste-oil produced biodiesel/diesel fuel blends. Fuel 2007, 86, 2810-2816.

37. Tesfa, B.; Mishra, R.; Zhang, C.; Gu, F.; Ball, A.D. Combustion and performance characteristics of CI (compression ignition) engine running with biodiesel. Energy 2013, 51, 101-115.

38. Tesfa, B.; Mishra, R.; Gu, F.; Powles, N. Prediction models for density and viscosity of biodiesel and their effects on fuel supply system in CI engines. Renew. Energy 2010, 35, 2752-2760.

39. Lin, B.F.; Huang, J.H.; Huang, D.Y. Experimental study of the effects of vegetable oil methyl ester on DI diesel engine performance characteristics and pollutant emissions. Fuel 2009, 88, 1779-1785.

40. Ulusoy, Y.; Tekin, Y.; Cetinkaya, M.; Karaosmanoglu, F. The engine tests of biodiesel from used frying oil. Energy Sources 2004, 26, 927-932.

41. Song, J.T.; Zhang, C.H. An experimental study on the performance and exhaust emissions of a diesel engine fuelled with soybean oil methyl ester. Proc. Inst. Mech. Eng. Part D J. Automob. Eng. 2008, 222, 2487-2496. 
42. Lin, C.Y.; Lin, H.A. Diesel engine performance and emission characteristics of biodiesel produced by the peroxidation process. Fuel 2006, 85, 298-305.

43. Labeckas, G.; Slavinskas, S. The effect of rapeseed oil methyl ester on direct injection Diesel engine performance and exhaust emissions. Energy Convers. Manag. 2006, 47, 1954-1967.

44. Srivastava, A.; Prasad, R. Triglycerides-based diesel fuels. Renew. Sustain. Energy Rev. 2000, 4, 111-133.

45. Lin, C.Y.; Chen, L.-W. Engine performance and emission characteristics of three-phase diesel emulsions prepared by an ultrasonic emulsification method. Fuel 2006, 85, 593-600.

46. Bazari, Z. Diesel Exhaust Emissions Prediction under Transient Operating Conditions. In Proceedings of the SAE International Congress and Exposition, 28 February-3 March 1994, Detroit, MI, USA; doi:10.4271/940666.

47. Raveendran, K.; Ganesh, A. Heating value of biomass and biomass pyrolysis products. Fuel 1996, $75,1715-1720$.

48. Raheman, H.; Phadatare, A.G. Diesel engine emissions and performance from blends of karanja methyl ester and diesel. Biomass Bioenergy 2004, 27, 393-397.

(C) 2014 by the authors; licensee MDPI, Basel, Switzerland. This article is an open access article distributed under the terms and conditions of the Creative Commons Attribution license (http://creativecommons.org/licenses/by/3.0/). 